\title{
Multiple syenite intrusions at Kærven, Kangerdlugssuaq, East Greenland: Evidence from the 1986 field work.
}

\author{
PAUL MARTIN HOLM, NIELS-OLE PRAGEL and EVA DEGN EGEBERG
}

\begin{abstract}
Holm, P. M., Progel, N.O. and Egeberg, E. D.: Multiple syenite intrusions at Karven, Kangerdlugssuaq, East Greenland: Evidence from the 1986 field work. Bull. geol. Soc. Denmark, vol. 38, pp. 173-181, Copenhagen, February 18th, 1991.

The Kærven Syenite Complex is recognized as the earliest intrusive body in the Kangerdlugssuaq region associated with the opening of the proto-Atlantic Ocean in the Lower Tertiary.

Earlier investigations of the geology of the Kærven Syenite Complex have interpreted the intrusion as a single igneous body, emplaced subsequent to the Kærven Gabbro and in turn cut by the Kangerdlugssuaq intrusion. Preliminary sampling on Kærven in 1977 revealed a relatively large range of rock types in the complex (syenite - alkali feldspar syenite - alkali feldspar granite). The field work conducted in 1986 has verified these findings and enabled the distinction of 8 intrusive events within the complex. Further, a preliminary geological map has been produced.

An igneous breccia separates the complex from the earlier Kærven Gabbro along parts of the eastern and southern margins. The central part of the Karven Syenite Complex include an hitherto unrecognized slice of Precambrian basement gneisses with numerous approximately N-S trending basaltic dykes. This is multiply intruded by syenite. Most notably in the eastern part of the complex, intimate associations of brecciated and remobilized basement gneiss and melts of syenitic through monzonitic to tonalitic compositions are found. The form of the intrusive bodies are more or less dyke-shaped and N-S trending. There is a general stratigraphic younging to the $\mathrm{SW}$, which is matched by the later adjacent Kangerdlugssuaq intrusion.

The intrusive sequence and trend of the intrusions are thought to be closely related to an extentional tectonic regime present in this part of the fjord for a considerable period onwards from the earliest
\end{abstract} Tertiary magmatic activity in the area.

Paul Martin Holm and Eva Degn Egeberg, Institute for Petrology, University of Copenhagen, $\emptyset_{\text {ster }}$ Voldgade 10, DK-1350, Denmark. Niels-Ole Pragel, Universitetsbiblioteket, University of Copenhagen, Nørre Alle 49, DK-2200, Denmark, January 16th, 1990.

\section{Introduction}

The Kærven Syenite Complex (KSC) is an early Tertiary intrusion belonging to the East Greenland Tertiary Province (e.g. Deer, 1976). Tholeiitic flood basalts and dykes are by far the most voluminous rock-types in the province, but in certain regions, e.g. around the Kangerdlugssuaq fjord, a large number of felsic intrusions dominate. The $\mathrm{KSC}$ with a ${ }^{40} \mathrm{Ar} /{ }^{39} \mathrm{Ar}$ age of ca. $58 \mathrm{Ma}$ (Holm, in prep.) is the hitherto oldest dated body and is apparently the first member in a series of felsic intrusions, culminating with the emplacement of the approximately $400 \mathrm{~km}^{2}$ large Kangerdlugssuaq intrusion. Other syenitic to granitic rocks in the Kangerdlugssuaq Fjord area occur in a number of other satellite intrusions to the Kangerdlugssuaq intrusion (Deer and Kempe, 1976) and intrusions along the fjord: Kap Boswell, Kap
Deichmann, Bagnæsset and Kræmer $\emptyset$, (Nielsen, 1987).

In a plate-tectonic context, it has been suggested that the Kangerdlugssuaq Fjord represents a failed arm established during the initial break-up of the American-Eurasian plate (Brooks, 1973). In this model the Kangerdlugssuaq area plays a key role in elucidating the phenomenons associated with the transition from continental to oceanic magmatism and may, in addition, hold information on the early manifestations of the active Icelandic mantle jet, (Brooks and Nielsen 1982; Holm, 1988). The KSC is an elongated (app, $3 \times 1 \mathrm{~km}^{2}$ ) intrusion located near the western shore of the Kangerdlugssuaq fjord, close to the point where the fjord has developed a prominent bend (fig. 1). The KSC is situated on the NE perimeter of the younger Kangerdlugssuaq intrusion which partly removed the western 


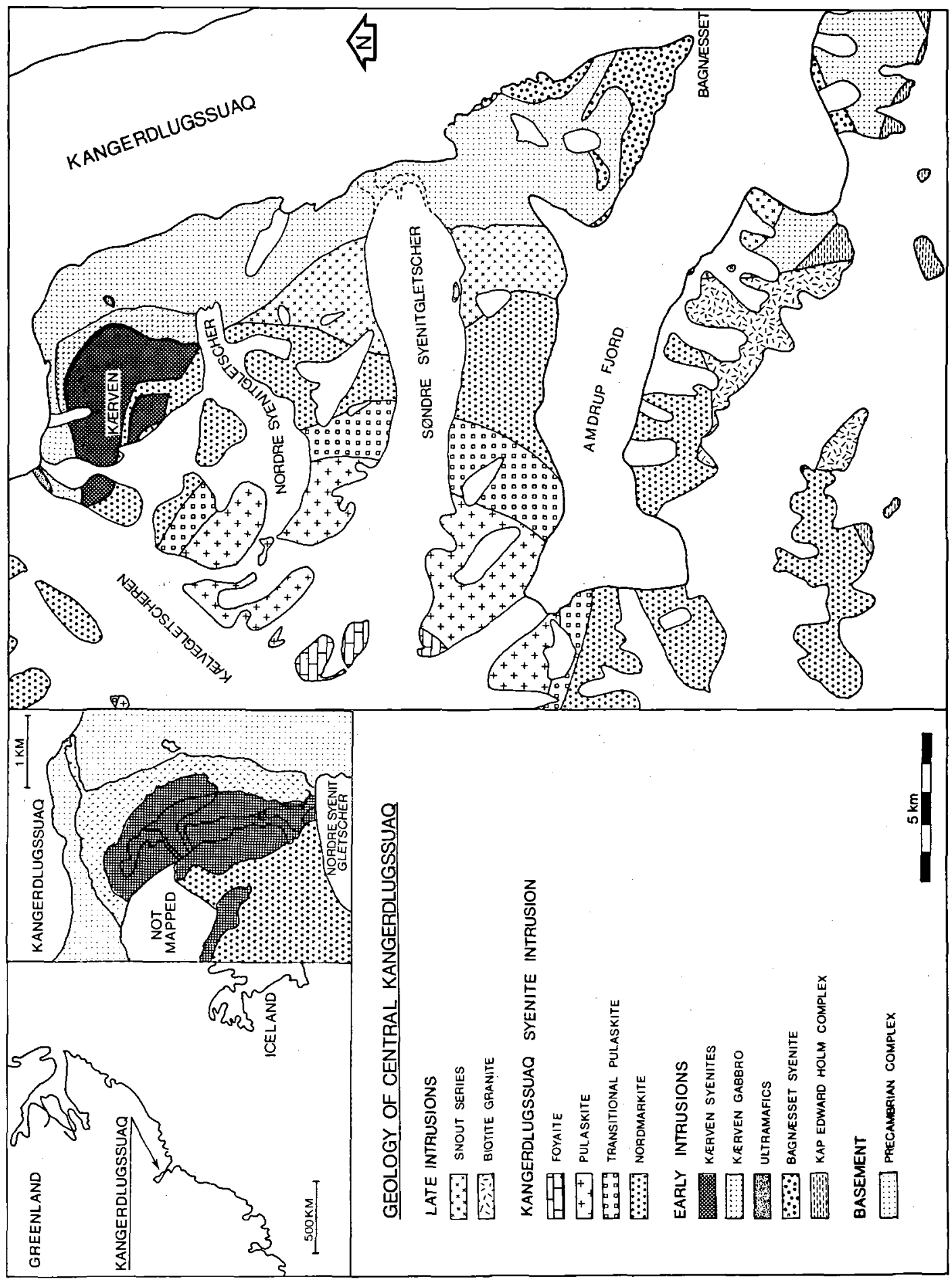

Fig. 1. Geological map of the Eastern part of the Kangerdlugssuaq intrusion and the adjacent area in the middle reaches of the Kangerdlugssuaq fjord. 


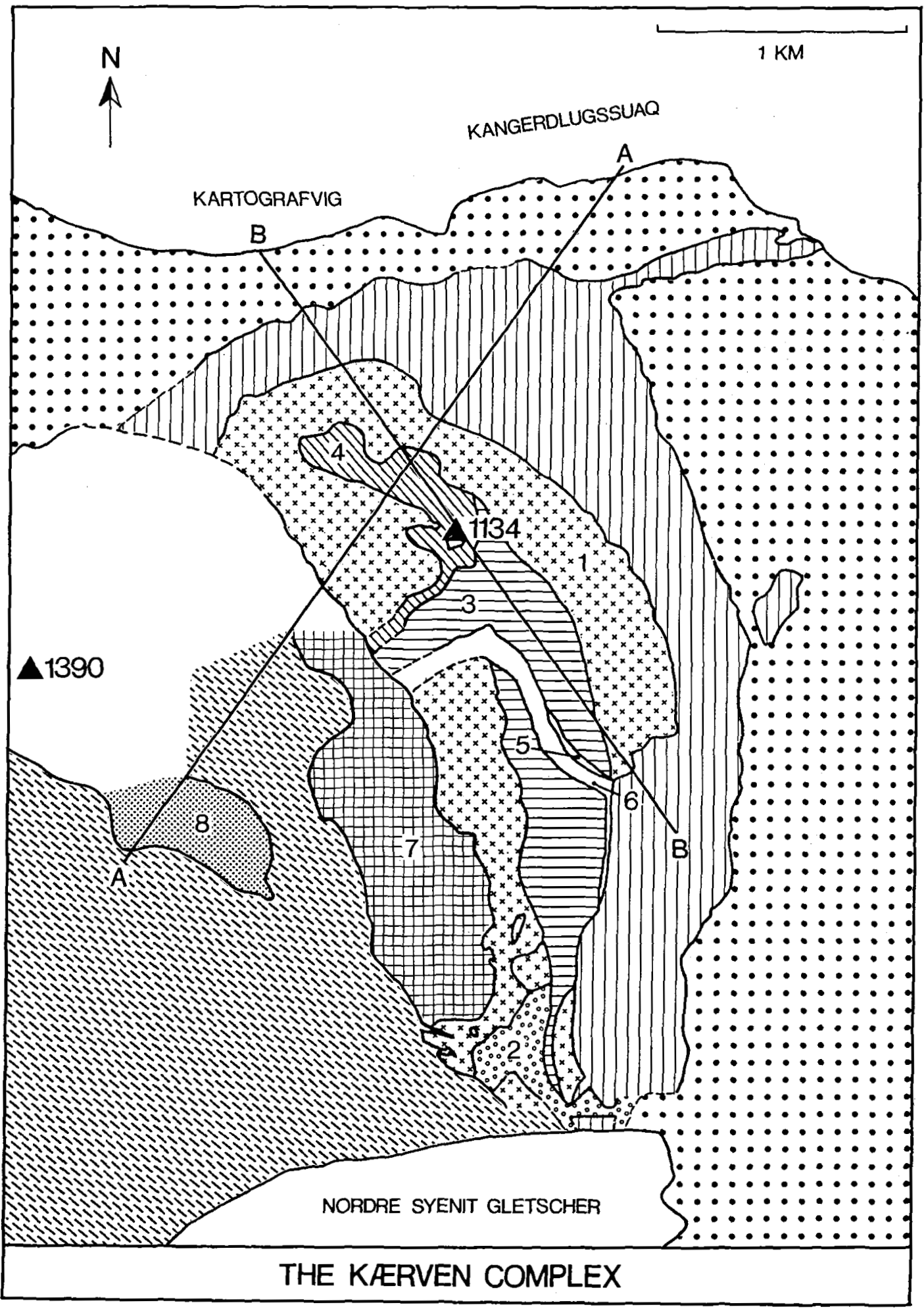

Fig. 2. Provisional geological map of the East and South part of the Kærven Syenite Complex with numbered intrusive units and the Kærven Gabbro (vertical ruling). Other signatures: Basement gneiss - dots; Basement segment shares signature with unit 1; nordmarkites - stipled ruling. 


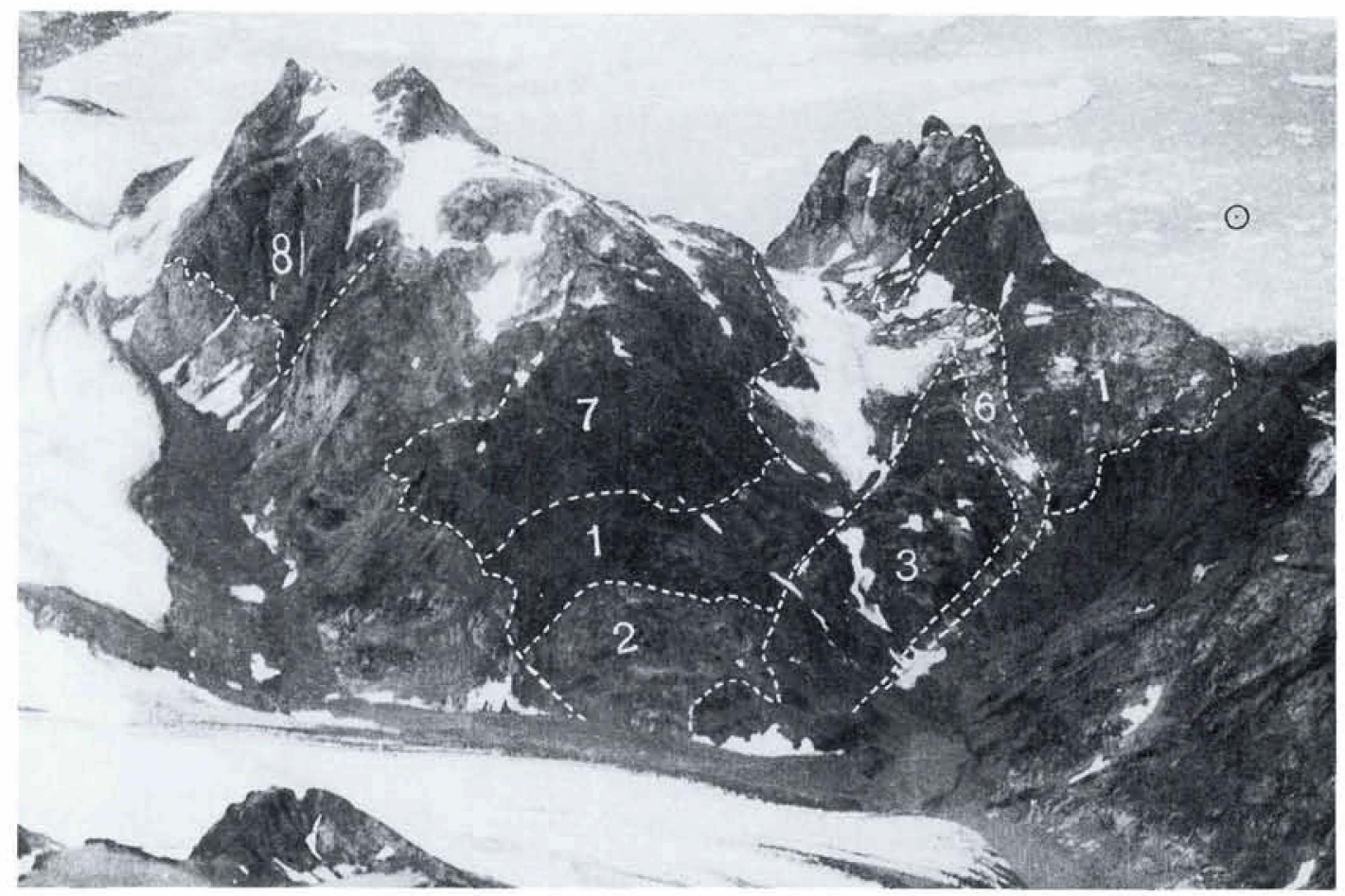

Fig. 3. Inclined aerial photo (British Arctic Air-rout Expedition, 1932. With the courtesy of the Danish Geodetic Institute) of Karven looking North with Nordre Syenitgletscher in the foreground. Main units of the complex are marked on the photo.

portions of the KSC. Along part of the eastern outer margin, the KSC is separated from the Archaean basement by a $200-800 \mathrm{~m}$ wide layered gabbro intrusion, the Kærven gabbro (Ojha, 1966). An intrusion breccia at the margin of the gabbro is locally developed in basement later reworked by the magmas of the KSC thus forming a second generation of igneous breccia. The northern part of the outer KSC margin is in contact with basement gneisses.

\section{Overview}

Mapping of the felsic units of the Kærven Syenite Complex (KSC) largely depended on the recognition in the field of different rock types and textural evidence for cooling. This proved difficult and in most cases required very short range inspection of the outcrops. Due to broad weathering zones, blasting proved a valuable additional means to the hammer. Eight major units could be distinguished in the complex. They are here named units 1 through 8 , and all form intrusive elongate bodies trending N-S to NW-SE (fig. 2). The succession has a general younging from NE towards WSW. The rock types span monzonites, syenites, quartz syenites, alkali feldspar quartz syenites and alkali feldspar granites in the IUGS system (Streckeisen, 1976). The contacts are mainly subvertical. An impression of the complex is presented in fig. 3 .

Approximately half the exposed area in the mapped part of the KSC consists of a segment of late Archaean basement which to a variable degree has been reworked by the intrusions. It outcrops on three sides of the eastern Karven peak $1134 \mathrm{~m}$ (fig. 2). Along the contact to the Kærven gabbro the basement is veined and brecciated to house sized blocks by monzonitic liquids. In the center valley of Kærven the gneisses are better preserved and less brecciated, but in the southern part of the outcrop they are densely intruded by basic dykes and other minor mafic and ultramafic intrusions. The basement is mainly tonalitic high grade rocks with some amphibolites.

Field investigations of the Kangerdlugssuaq in- 
Tab. 1. Representative analyses of the units of the KSC.

\begin{tabular}{|c|c|c|c|c|c|c|c|}
\hline & 1 & 2 & $\begin{array}{c}\text { ive Uni } \\
3\end{array}$ & $\begin{array}{c}\text { he Kærv } \\
5\end{array}$ & $\begin{array}{c}\text { nite Cor } \\
6\end{array}$ & 7 & 8 \\
\hline $\mathrm{SiO}_{2} \mathrm{wt} \%$ & 65.55 & 66.65 & 65.07 & 71.20 & 72.91 & 63.59 & 73.77 \\
\hline $\mathrm{TiO}_{2}^{2}$ & 0.48 & 0.45 & 0.78 & 0.41 & 0.25 & 1.32 & 0.27 \\
\hline $\mathrm{Al}_{2} \mathrm{O}_{3}$ & 16.14 & 15.71 & 14.65 & 13.89 & 13.10 & 13.41 & 12.83 \\
\hline $\mathrm{Fe}_{2} \mathrm{O}_{3}$ & 1.92 & 0.94 & 1.92 & 1.58 & 0.62 & 3.13 & 1.13 \\
\hline $\mathrm{FeO}$ & 2.43 & 2.50 & 3.78 & 2.02 & 1.86 & 4.64 & 1.19 \\
\hline $\mathrm{MnO}$ & 0.14 & 0.14 & 0.18 & 0.14 & 0.10 & 0.27 & 0.08 \\
\hline $\mathrm{MgO}$ & 0.72 & 0.21 & 0.52 & 0.19 & 0.04 & 0.93 & 0.08 \\
\hline $\mathrm{CaO}$ & 1.97 & 0.93 & 1.40 & 0.83 & 0.33 & 2.15 & 0.33 \\
\hline $\mathrm{Na}_{2} \mathrm{O}$ & 5.51 & 5.39 & 5.58 & 4.17 & 4.14 & 4.76 & 4.30 \\
\hline $\mathrm{K}_{2} \mathrm{O}$ & 3.63 & 5.29 & 4.97 & 5.26 & 5.24 & 4.12 & 5.09 \\
\hline $\mathrm{P}_{2} \mathrm{O}_{5}$ & 0.26 & 0.08 & 0.80 & 0.07 & 0.03 & 0.48 & 0.04 \\
\hline L.o.i. & 0.51 & 0.49 & 0.11 & 0.47 & 0.41 & 0.77 & 0.49 \\
\hline sum & 99.26 & 98.78 & 99.76 & 100.23 & 99.03 & 99.57 & 99.60 \\
\hline
\end{tabular}

trusion in the area $\mathrm{N}$ of Nordre Syenitgletscher revealed no obvious variation in the quartz content of the nordmarkites in this part of the intrusion, thus contrasting to the results of previous workers (e.g. Kempe et al., 1970). Moreover, a gradational transition from nordmarkite to transitional pulaskite, two of the main units of the Kangerdlugssuaq intrusion, could not be confirmed. Although the contact is not exposed at the two investigated transition localities, strongly contrasting rock-types outcrop only a few meters apart both on the north side of Nordre Syenitgletscher and on a nunatak south of Kalvegletscher. Moreover, the nordmarkite body to the $\mathrm{W}$ of $\mathrm{KSC}$ is petrographically extremely ho-

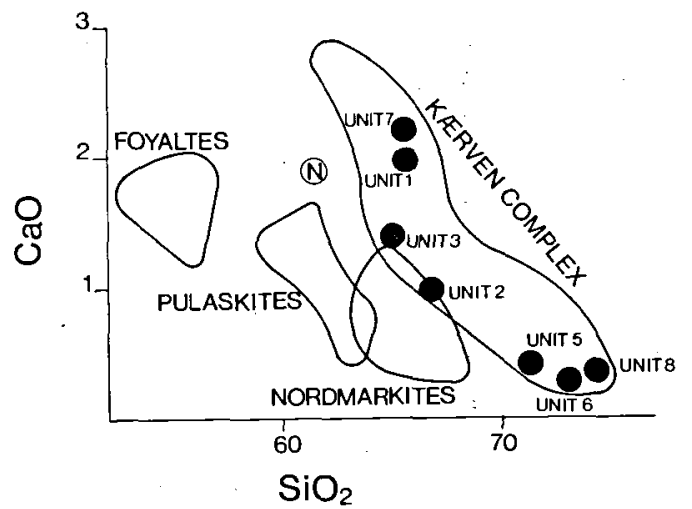

Fig. 4. Harker variation diagram for $\mathrm{CaO}$ showing the composition of representative samples (Table 1) of the units of the KSC. Also shown for comparison is analyses from the Kangerdlugssuaq intrusion (ruled areas) $-\mathrm{N}$ is nordmarkite basement melts (open circles) and variation of the KSC from Holm and Prægel (1988). mogenous and does not display any sign of gradation. It is thus inferred from this evidence that the nordmarkites W of the KSC constitute an independent intrusion of rather homogenous composition emplaced after unit 8 of the KSC. Previously no evidence for the multiplicity of the Kangerdlugssuaq intrusion has been presented. However, Brooks and Gill (1982) pointed out that the mineral chemistry of the mafic minerals of the Kangerdlugssuaq intrusion showed variation not fully explained by a crystal fractionation evolutionary model. Also Nielsen (1987) cited personal communication with $\mathrm{C}$. $\mathrm{K}$. Brooks, who had observed an intrusive sheet of pulaskite in the nordmarkites by Amdrup Fjord.

\section{The intrusive units}

Some characteristic features of the units of the KSC are outlined below in chronological order according to the mapped sequence of intrusion. Major element analyses of samples from the individual units are presented in Table 1 and illustrated in the Harker diagram, fig. 4.

\section{Unit 1 (monzonitic)}

The earliest Tertiary felsic magma intruded and brecciated both the basement immediately $W$ of the gabbro, basic dykes in the basement, which partly originated from the gabbro, and the gab- 
bro-breccia zone adjacent to the gabbro. The basement was brittle at the time of monzonite intrusion possibly indicating that the monzonite was not emplaced immediately subsequent to the gabbro intrusion. The main part of this rock type occurs as a NW-SE trending $100 \mathrm{~m}$ wide central zone in the basement SE and $E$ of peak $1134 \mathrm{~m}$, and grades into the surrounding basement as the matrix to rounded and angular mega blocks of gneiss and angular rafts of basic dykes, which were detached from their basement hosts during brecciation.

The monzonite is a medium-grained white or yellowish and black spotted rock. In hand specimen feldspar, quartz and biotite are seen. The characteristic and distinguishing feature of the monzonite is the large amount of modal plagioclase $(20-45 \%)$. The composition has not yet been acquired but analytical results from the complex have recently been published (Holm and Prægel, 1988). Alkali feldspar forms a major part in some samples $(25-50 \%)$ while being absent in others. Thus the rock type range from tonalite over monzonite to quartz syenite. Compared to the syenites, the monzonites have higher modal amount of mafic minerals $(7-10 \%$ amphibole, $1-5 \%$ clinopyroxene and $1-5 \%$ biotite). Olivine is not found in this unit. The accessory phases include sphene.

\section{Unit 2 (quartz syenite)}

This syenite only outcrops at the southern tip of the complex just $N$ of Nordre Syenitgletscher. It intrudes the basement segment to the $\mathrm{N}$ where an intrusion breccia is developed along the NE-SW running contact. Prominent in the breccia are rounded basaltic blocks which seem to have been liquid at the time of incorporation into the syenitic magma but brecciated by the syenite during the emplacement. The syenite also cuts through the gabbro. The syenite was prior to the emplacement of unit 3 in contact with the basement segment also to the $\mathrm{E}$. The contact to the nordmarkite of the Kangerdlugssuaq intrusion is a ca. $20 \mathrm{~cm}$ wide zone of hybid rock rich in fine to medium grained mafic minerals, which does not allow the direct age relation between the two to be revealed. However, by inference of the age relationship of units 2,3 and 7 the unit 2 syenite is older than the nordmarkite.
Unit 2 quartz syenite is a medium grained equigranular reddish rock-type with ca. $80 \%$ euhedral perthite (1-5 mm), 5-10\% anhedral quartz (1-2 $\mathrm{mm})$, late-stage green anhedral clinopyroxene $(3-5 \% ; 1-2 \mathrm{~mm})$ and brownish anhedral amphibole (7-10\%; up to $3 \mathrm{~mm}$ ). Interstitial olivine a few tenth of a $\mathrm{mm}$ is occasionally seen. Accessories include apatite and opaques.

Unit 3 (quartz alkali feldspar syenite - alkali feldspar granite)

This intrusion makes up the S face of the E 1134 $m$ peak of Kærven and has the red-brown weathering colour associated with the general appearance of Krrven. This is due to the alteration of olivine. The intrusion is a dyke-like unit, $250-300$ $\mathrm{m}$ wide and trending from $\mathrm{S}$ to $\mathrm{N}, \mathrm{N}-\mathrm{S}, \mathrm{NW}-\mathrm{SE}$ and SW-NE. At the southern termination it narrows to a thin wedge which ends just $\mathrm{N}$ of Nordre Syenitgletscher, where it intrudes the earlier contact between units 1 and 2. More northerly it intrudes the central part of unit 1 and ca. $100 \mathrm{~m} \mathrm{~S}$ of peak 1134 the intrusion turns sharply $\left(90^{\circ}\right)$ to the W. It is clearly intruded by the later syenite and granite units 4,5 and 6 , while the contact to unit 7 is covered by ice and snow in the central valley. The contact to unit 1 is not a chill and at places it is difficult to distinguish the two units but unit 3 is clearly emplaced into unit 1 , eventhough they may be nearly contemporanoeous.

The syenite is equigranular and medium grained and with up to $10 \%$ small grey alkali feldspar phenocrysts. The rock is characterised by $3-5 \%$ small $(0.1-1.5 \mathrm{~mm})$ bright redbrown, semi-translucent, euhedral interstitial olivines. In thin section $50-80 \%$ euhedral microperthite (3-6 $\mathrm{mm}$ ) and $2-40 \%$ anhedral interstitial $1 \mathrm{~mm}$ quartz grains are seen. Plagioclase is only occasionally found as cores in the perthites. The dominant mafic phase $(5-10 \%)$ is a late interstitial amphibole $0.5-1 \mathrm{~mm}$ large grains. A greenish, sometimes euhedral clinopyroxene preceeded amphibole in some samples. Biotite is present in some samples in accessory amounts together with zircon and apatite. The apparant general crystallization sequence is ol $>\mathrm{cpx}>$ amph and feldspar > qz. 


\section{Unit 4 (alkali feldspar granite)}

The ridge of peak $1134 \mathrm{~m}$ and the upper $300 \mathrm{~m}$ of the north cliff face consist of a second red-brown weathering syenite only slightly darker than unit 3. This dyke like intrusion is petrographically almost identical to unit 3 . The NE contact to unit 1 is not exposed, but a few outcrops of monzonite observed high in the cliff suggests the present cliff face to be following the original plane from which the less resistant monzonite was removed during the last glaciation. The Western contact to unit 1 was seen only from the distance.

This syenite unit is petrographically very distinct and is composed of ca. $60 \%$ euhedral perthite phenocrysts (up to $4 \mathrm{~mm}$ ) in a matrix dominated by anhedral $0.1-0.5 \mathrm{~mm}$ quartz $(40 \%)$ positioned along perthite margins. Corroded mafic groundmass phases are olivine and possibly clinopyroxene and amphibole. Opaques are accessory.

\section{Unit 5 (granite)}

At the present level of erosion only a few $m$ thin NW-SE trending screan of this unit is exposed. In cross section it forms a wedge chilled against unit 3 and cut by the subsequent unit 6 . Unlike all the other dyke like vertical units this unit has an inclined contact of $45^{\circ}$ to unit 3. Both contact planes of unit 5 strike NW-SE.

The unit 5 granite is a white medium grained rock with rare clots of intermediate to mafic, feldspar phyric, fine grained, rounded inclusions. It is composed of up to $80 \% 2.4 \mathrm{~mm}$ microperthite, around $15 \mathrm{vol} \%$ quartz, and ca. $1 \%$ plagioclase. Quartz occurs both as discrete grains and in graphic intergrowth with alkali feldspar. Subordinate amounts of amphibole and green clinopyroxene account for $<10 \mathrm{vol} \%$ of the granite.

\section{Unit 6 (alkali feldspar granite)}

This unit outcrops as a ca. $100 \mathrm{~m}$ wide dyke with horizontal columnar jointing. The dyke is vertical and can be divided into three parts striking N-S, NW-SE and SW-NE very similar to the style of intrusion of the larger unit 3 . It is chilled against the syenites of unit 3 . The geometry of units 3,5 and 6 , clearly suggests unit 6 to be the youngest eventhough the contacts do not clearly show the age relationships.

The rock is light grey to white sometimes with a pinkish weathering colour. It has ca. $10 \%$ phenocrysts of white alkali feldspar up to $3 \mathrm{~mm}$ in size and sparse smaller of black amphibole. The colour index is ca. 10. The groundmas is granitic in composition. This rock-type has ca. $10 \%$ phenocrystic microperthite $(3-3.5 \mathrm{~mm})$ and small amounts of brownish/green amphibole (up to 2 $\mathrm{mm}$ ), green clinopyroxene (ca. $1 \mathrm{~mm}$ ) and yellowish olivine (ca. $0.5 \mathrm{~mm}$ ) phenocrysts. The groundmass consists of ca. $65 \%$ perthite $(0.5-0.8$ $\mathrm{mm}), 20 \%$ quartz $(1.5-0.01 \mathrm{~mm})$, amphibole, clinopyroxene and opaques. The groundmass quartz is anhedral and occurs mainly along feldspar margins in recrystallized fashion or in graphic intergrowths with feldspar.

\section{Unit 7 (syenite).}

This unit constitute the $W$ side of the valley between the two main peaks of the Kærven massif. The steep cliff of the valley has its form due to the contrast in resistance to glacial ice between this syenite and the central basement segment, an analog to the contact for units 1 and 4 . Also this syenite is olivine bearing and appear reddishbrown on weathered surfaces. Although the contact does not outcrop, this unit must postdate units 3,4 and 6 as these do not cut through unit 7 on the $\mathrm{W}$ side of the ice and snow covered valley $E$ of unit 7. The syenite is in turn cut by the nordmarkite of the Kangerdlugssuaq intrusion. The less regular margins of this unit may be caused by the high ambient temperature in the country rock during emplacement.

Consists of ca. $75 \%$ euhedral perthite (2-4 $\mathrm{mm}), 10 \%$ anhedral interstitial quartz and ca. $15 \%$ anhedral amphibole $(0.1-1 \mathrm{~mm})$. Small amounts of biotite and plagioclase occurs in the groundmass. Apatite and zircon are accessories. This rock unit includes some fine grained $(0.5-1$ $\mathrm{mm}$ ) domains of perthite, quartz and amphibole.

\section{Unit 8 (alkali feldspar granite)}

The relative age of this unit cannot be related to the other as it occurs as an inlier in the nord- 
markite as far as mapping has presently progressed.

Also this unit carries the characteristic reddish colour of the main units of the KSC. Further it has small $\mathrm{cm}$ sized basic to intermediate inclusions along the Western contact. It is an alkali feldspar granite with ca. $5 \%$ phenocrysts of grey 3-6 $\mathrm{mm}$ alkali feldspar with white rims. Consists of $60 \%$ euhedral perthite (up to $4 \mathrm{~mm}$ ), 35\% subhedral quartz $(1 \mathrm{~mm}), 4 \%$ brownish anhedral amphibole and $1 \%$ green clinopyroxene (anhedral, ca. $0.5 \mathrm{~mm}$ ). Small corroded crystals are probably olivine.

\section{Conclusions}

Contrary to the earlier conception of the geology of the Kærven Syenite Complex (Deer and Kempe, 1976), the present results of the 1986 fieldwork is the first documentation that the complex is a multiple intrusion comprising 8 major salic rock units which can be distinguished on the basis of field occurrence and petrography. With regard to the Kangerdlugssuaq intrusion the basis for accepting this large body as one batch of magma was the unsuccessful search for contact between rock units in that intrusion and the reported gradational modal composition of the rock types (Kempe et al., 1970). The style of intrusion at Kærven of a number of dyke-formed bodies in a rather complex manner is therefore very much in contrast to that view on the genesis of the adjacent and later Kangerdlugssuaq intrusion. The style is probably comparable to some of the central complexes in the Tertiary Hebridean Province (e.g. Thompson, 1980), although there is no clear indication that Kærven is a central complex.

It was unexpected to find relatively large areas of more or less reworked basement rocks in the KSC (fig. 2). The syenitic rocks therefore make up a much smaller part of the complex than previously assumed. We estimate on an outcrop-basis that only approximately $50 \%$ af the $\mathrm{KSC}$ in the area presented here is occupied by syenite. A further result of the mapping is the recognition in the central basement segment at Kærven of relatively large amounts of basic material which testify to an important early basic magmatic episode in the evolution of the area.
It has been possible to establish a relative age sequence of the intrusive units comprising the KSC. The Kærven Gabbro locally brecciate the basement rocks and this breccia is itself brecciated by the monzonite. The monzonite is followed by five syenite pulses which have contact relations to the monzonite/basement unit. The time sequence of these syenites can be elucidated by chills and other contact relations. The later unit 7 cuts units 3,4 and 6 , while unit 8 may be identical to unit 7 but separated from the latter by the intrusion of the nordmarkite of the Kangerdlugssuaq intrusion.

Eight new major element analyses of the mapped rock units of the KSC are presented. The composition of the analysed samples are within the range reported by Holm and Prægel (1988) for KSC. The improved geological understanding of the complex will be the basis for a detailed geochemical and isotope geological study.

The intrusive evolution of the Kærven Syenite Complex seems to be governed by a NW-SE zone parallel to the fjord which can possibly be related to the suggested failed arm model. Also the Kærven gabbro and the numerous dykes in the central basement segment inside KSC have the same trend indicating the existence of a tensional tectonic environment in this part of the fjord for a period ranging from ca. $59 \mathrm{Ma}$ through $53 \mathrm{Ma}$ when the youngest Kærven units were intruded (Holm, in prep). The chronological sequence of felsic intrusion indicate a movement of the focus of magma transport towards the SW, which may have been related to the relative position of a rift. This evolution may have continued also during the subsequent emplacement of the Kangerdlugssuaq intrusion which terminated ca. $49 \mathrm{Ma}$ (Pankhurst et al., 1976). The implication from the study of the nordmarkite W of KSC is that possibly also the Kangerdlugssuaq intrusion is composed of a number of discrete units which may be interpreted from the existing geological map and the N-S trending $E$ and $W$ contacts of the nordmarkite to be dyke shaped and approximately fjord parallel. The concept of the Kangerdlugssuaq fjord as a failed arm of a triple junction is thus supported by this evidence of prolonged crustal extension parallel to the fjord starting earlier than the first eruptions of lava and not ending until well after active ocean spreading was established. 


\section{Acknowledgments}

The fieldwork in the KSC and the adjoining parts of the Kangerdlugssuaq intrusion, which forms the basis of the present account, was conducted from mid-July to mid-August 1986. The Kangerdlugssuaq area is very inaccessible especially so after the close down of the weather station at Aputiteq, which means that all traffic to and from Kangerdlugssuaq goes by air via Iceland. The logistic support was provided by Grønlands Geologiske Undersøgelse and Geodætisk Institut and is much acknowledged. Two camps were established in the Kærven area; helicopter courtesy of the GI/GGU made it possible to locate camps at sites not readily accessible otherwise, and to arrange swift camp moves. The Danish Natural Science Research Council funded the field work.

\section{Dansk sammendrag}

Kærven Syenit Komplekset er en tidlig tertiær intrusion beliggende på vestsiden af Kangerdlugssuaq-fjorden, Østgrønland, og udgør en perifer intrusion til den senere Kangerdlugssuaq intrusion (fig. 1).

Kangerdlugssuaqområdets betydning ved udredningen af de tektoniske og magmatiske processer med tilknytning til den begyndende åbning af Nordatlanten i nedre Tertiar er velkendt, og Kærven Syenit Kompleksets alder indicerer, at komplekset udgør en af de tidligste erkendte magmatiske begivenheder i Kangerdlugssuaqområdet med relation til den begyndende oceanbundsspredning.

Kxrven Syenit Komplekset, der måler ca. $6 \times 5 \mathrm{~km}^{2}$, intruderer den tertiære Kærven Gabbro, der igen intruderer det arkæiske grundfjeld (fig. 2 og 3). Komplekset er mod SV skåret af kvartsnordmarkiter tilhørende Kangerdlugssuaq Intrusionen.

Kærven Syenit Komplekset har, i lighed med de øvrige felsiske intrusioner i Kangerdlugssuaqområdet, hidtil været betragtet som et enkelt intrusivt legeme. De foreløbige resultater af feltarbejdet $i 1986$ dokumenterer imidlertid entydigt, at komplekset er en multipel intrusion, opbygget af i hvert fald otte separate felsiske enheder. Disse forekommer $i$ aflange gangagtige legemer (N-S til NV-S $\emptyset$ ) med en relativ aldersprogression mod SV. Kærven kompleksets felsiske intrusiver varierer fra monzonit over syenit til alkali feldspat kvarts syenit og granit. Kemiske analyser (Tabel 1 og fig. 4) ligger i det interval, som tidligere er præsenteret fra komplekset (Holm og Prægel, 1988). En stor del af komplekset (ca. $50 \%$ af området reprasenteret i fig. 2) udgøres af et hidtil ikke erkendt mere eller mindre metamorfoseret segment af grundfjeld, der især $\mathbf{i}$ området mellem Kærvens $1390 \mathrm{~m}$ og $1134 \mathrm{~m}$ toppe er intenst intruderet af $\mathrm{N}-\mathrm{S}$ gående basaltiske gange og af uregelmæssige mafiske og ultramafiske legemer.

Rekononcerende feltarbejde på de til Kærven Syenit Kom- plekset grænsende bjergarter, tilhørende Kangerdlugssuaq Intrusionen, antyder, at denne ligeledes kan omfattes som multipel.

\section{References}

Brooks, C.K. 1973: Tertiary of Greenland - A Volcanic and Plutonic Record of Continental Break-up. Mem. Am. Assoc. Petrol. Geologists 19: 150-160.

Brooks, C.K. and Gill, R.C.O. 1982: Compositional variation in the pyroxenes and amphiboles of the Kangerdlugssuaq Intrusion, East Greenland: Further evidence for the crustal contamination of a syenite magma. Mineral. Mag. 45: $1-9$.

Brooks, C.K. and Nielsen, T.F.D. 1982: The Phanerozoic development of the Kangerdlugssuaq Area, East Greenland. Meddr. Grønland 9, 31pp.

Deer, W.A. 1976: Tertiary igneous rocks between Scoresby Sund and Kap Gustav Holm, East Greenland. In Escher, A. and Watt, W.S. (eds.): Geology of Greenland. Grønlands Geologiske Undersøgelse, København, p. 405-429.

Deer, W.A. \& Kempe, D.C.R. 1976: Geological investigations in East Greenland, part XI: The minor peripheral intrusions, Kangerdlugssuaq, East Greenland. Meddr. Grønland 197/4: 25pp.

Holm, P.M. 1988: $\mathrm{Nd}, \mathrm{Sr}$ and $\mathrm{Pb}$ isotope geochemistry of the Lower Lavas, E Greenland Tertiary Igneous Province, In: Morton, A.C. and Parson, L.M. (eds.): Early tertiary Volcanism and the Opening of the NE Atlantic. Geol. Soc. London Spec. Publ. 39, 181-195.

Holm, P.M. \& Pragel, N.-O: The Tertiary Karven Syenite Complex, Kangerdlugssuaq, East Greenland: Mineral Chemistry and geochemistry. Mineral. Mag. 52: 435-450.

Kempe, D.R.C., Deer, W.A. \& Wager, L.R. 1970: Geological investigations in East Greenland, part VIII: The petrology of the Kangerdlugssuaq Alkaline intrusion, East Greenland. Meddr. Grønland 190/2: 49pp.

Nielsen, T.F.D. 1987: Tertiary alkaline magmatism in E Greenland: a review. In: Fitton, J.G. and Upton, B.G.J. (eds.): Alkaline Igneous Rocks, Geol. Soc. London Spec. Publ. 30, 489-515.

Ojha, D.N. 1966: Petrology of the Kærven Layered Intrusion, East Greenland. J. Geochem. Soc. India 1: 86-112.

Pankhurst, R. J., Beckinsale, R.D. \& Brooks, C. K. 1976: Strontium and Oxygen Isotope Evidence Relating to the Petrogenesis of the Kangerdlugssuaq Alkaline Intrusion, East Greenland. Contrib. Mineral. Petrol. 54: 17-42.

Streickeisen, A.L. 1976: To each plutonic rock a proper name. Earth Sci. Rev. 12: 1-33.

Thompson, R.N. 1980: Askja 1875, Skye 56 Ma: Basalt-triggered, Plinian, Mixed-magma Eruptions during the Emplacement of the Western Redhill Granites, Isle-of-Skye, Scotland. Geol. Rundschau 69: 245-262. 